\title{
Exploring the e-CRM - e-customer- e-loyalty nexus: a Kenyan commercial bank case study
}

\author{
Timothy K. OUMAR \\ Jesuit Historical Institute in Africa, Nairobi, Kenya \\ Eric E. MANG'UNYI \\ Walter Sisulu University, Mthatha, South Africa \\ Krishna K. GOVENDER \\ University of KwaZulu-Natal, Pietermaritzburg, South Africa \\ govenderkrishna@gmail.com \\ Sookdhev RAJKARAN \\ Walter Sisulu University, Mthatha, South Africa
}

\begin{abstract}
This article scaffolds on customer relationship management (CRM) theory and explores the association between electronic CRM (e-CRM) and electronic customer's (e-customer) electronic loyalty (e-loyalty) in the banking sector. By using a survey design, data was collected from a convenience sample of customers of a major Kenyan commercial bank, and analysed using structural equation and multiple regression modelling. The findings reveal that there is a positive relationship between $e$-CRM and e-customers' loyalty. The e-CRM features at all three stages of an electronic transaction cycle namely, pre-service, during-service and after-service, significantly influence the e-customers' loyalty in the banking sector. Thus, to capitalize on the range of benefits that emanate from the use of e-CRM, continued review and enhancement of marketing strategies is needed, so as to achieve e-customers' loyalty particularly, at the post-service stage. Kenyan commercial bank managers should focus on customer satisfaction specifically at post-service stage, to increase their ecustomers' loyalty.
\end{abstract}

Keywords: Customer loyalty, e-CRM, Service satisfaction, Relationship management, Relationship marketing, On-line Banking; Banking industry.

Please cite the article as follows: Oumar, T K., Mang'unyi, E E, Govender, K K. and Rajkaran, S. (2017), "Exploring the e-CRM - e-customer- e-loyalty nexus: A Kenyan commercial bank case study", Management \& Marketing. Challenges for the Knowledge Society, Vol. 12, No. 4, pp. 674-696. DOI: 10.1515/mmcks-2017-0039.

\section{Introduction}

Customer relationship management (CRM) is a critical tool that assists an institution to tap into a range of business benefits such as revenue, customer satisfaction, allegiance (Koçoglu and Kirmaci, 2012; Nguyen and Mutum, 2012; Safa and von 
Solms, 2016) and effective marketing and communication between the firm and the customer (Gikenye, 2011; Lendel and Varmus, 2015), loyalty, efficiency and cost reduction (Ahmad, Rashid and Ul-Mujeeb, 2012; Dolly and Pruthi, 2014). Basically, customer relationship management is managing relationships with customers (Harrigan, Ramsey and Ibbotson, 2012, p. 41; Khoshtinat, Bojei and Ahmadin, 2014), which is vital to service quality and a quick response to market changes (Jamali, Moshabaki, Aramoon and Alimohammadi, 2013, p. 120). Electronic customer relationship management (e-CRM) is a relatively new area of research heralded as the new paradigm of marketing (Bhanu and Magiswary, 2010; Thuo et al., 2011), a concern in the current banking industry (Dhingra and Dhingra, 2013), and is used as a strategy to enhance organisational flexibility (Jamali et al., 2013, p. 120). e-CRM is essentially, managing customer relationships by electronic means (Ismail and Hussin, 2016) while, enabling organisations such as banks to provide appropriate services and products that satisfy customers and enhance their loyalty. e-CRM combines people, processes and technology, and seeks to understand the buyerseller relationship. Researchers such as Malik and Kumar (2013) and Muro et al. (2013) assert that e-CRM is a strategic technology-centric relationship marketing business model, combining traditional CRM with e-business market place applications. The Internet, web technologies like emails and databases facilitate the implementation of e-CRM (Abu-Shanab and Anagreh, 2015; Harrigan et al., 2012) as its attention is on a web-based interaction platform between the institution and its customers (Abdulfattah, 2012). This means that a large percentage of customer interactions take place over the Internet, mostly via electronic media as opposed to face-to-face with an organisation's employees. Therefore, features that make up eCRM remain critical for managing online customer relationships, while building loyalty. These features constitute concrete website or internet-based tools, integrated into organisational systems which when properly customised, enable the required interaction with the customer (Jamali et al., 2013; Hosseini et al., 2016).

The Internet provides the vehicle to deliver CRM applications via the Web, and as business services are moved to the web, e-CRM takes the centre stage. The relationship with the customer cannot therefore be realised on the Internet without effective e-CRM strategies. To be effective, relationship management requires commitment and an over-arching strategic CRM ethos (Govender, 2004). Whereas customer satisfaction is a precursor to loyalty (Malik and Kumar, 2013), it still remains a perplexing task in the world of electronic business, since businesses are trying to deploy CRM and improve relationships with customers to gain and retain their loyalty. While customer loyalty has been associated with business success (Khoshtinat et al., 2014; Safa and von Solms, 2016), achieving this in the electronic banking context remains a daunting task for many bank managers in the current dynamic global e-businesses environment. Banks are aggressively trying to position e-CRM and improve the relationship between the business and customer to increase efficiency and ensure continual business survival. Since it is not easy to have direct contact with e-CRM customers (Harrigan et al., 2012), dissatisfied customers are 
likely to seek other service providers when there is a lack of good relationship management via internet. It is against the above background, that this study strives to understand the current state of e-CRM in the respective banking sector and explore the key drivers of customer satisfaction and loyalty.

The extant literature only reports on the relationship between traditional CRM and customer loyalty. Furthermore, previous studies have failed to investigate the internet-based CRM components and their linkage to the electronic customers' (e-customer) electronic loyalty (e-loyalty). By drawing heavily on the CRM literature, this article attempts is to contribute to a less researched area of customer relationship management and e-customers' e-loyalty in relation to the banking industry.

\section{Literature review}

Globally, the adoption of e-CRM and its rising performance has been a fairly recent phenomenon in the majority of businesses, disciplines such as marketing and information technology (Adalikwu and Adalikwu, 2013), and particularly in developing countries. As such, managers have strategically invested in current technologies while emphasising building and maintaining worthy linkages with customers (Abu-Shanab and Anagreh, 2015; Harrigan et al., 2012; Nguyen and Mutum, 2012; Thuo et al., 2011). Merging technology, processes and other activities associated with the customer have facilitated CRM application (Harrigan et al., 2012; Abdulfattah, 2012), enabling organisations to recognise the best customer, increase their satisfaction with and loyalty to the service offerings (Alhaiou et al., 2012).

The effective use of relationship marketing can help to create competitive advantage (Dhingra and Dhingra, 2013; Harrigan et al., 2012; Thuo et al., 2011); and firms that have implemented fundamental e-CRM practices are reaping numerous benefits, ranging from superior customer service, improved profitability, sales, reduced operational costs, enlarged customer base and a broader market share (Jamali et al., 2013; Kihara, 2015; Stojković and Đuričić, 2012). Since the aforementioned positive benefits emanating from e-CRM practices are associated with customer satisfaction, it is important to create more value for customers through nurturing interpersonal relations that lead to repeat purchases that benefit both the business and consumer. The aforementioned is supported by Lam, Cheung and Lau (2013) and Bilgihan and Bujisic (2014) who argued that a positive relationship between a customer and the organisation will create customer loyalty. Faithful customers tend to conduct repeat purchases, regardless of the prices and they also likely to refer others; hence it is economically cheaper to maintain (Lam et al., 2013). The aforementioned researchers established that the quality of customer relationship impacts positively on customer loyalty, and they further claim that systematic implementation of e-CRM will deepen customer loyalty towards a company (Lam et al., 2013). Safa and von Solms, (2016) opines that loyal customers are vital to the survival and success of many service industries, especially in the financial sectors, hospitality and airline. The aforementioned researchers further 
argue that a small variation in the percentage of loyal customers is said to bring about a huge change in profits and also the overall value of a business.

Some studies (Abdulfattah, 2012; Dhingra and Dhingra, 2013) on the use of e-CRM in building customer relationships established that it affects online customer satisfaction and service quality. The aforementioned also suggested that an efficient e-CRM program governing online features need to be effected on an online service platform. Similarly, (Maroofi et al., 2012; Sivaraks et al., 2011) studies provided intuitions important paradigm shifts in online services by revealing the main role of e-CRM in satisfaction formation, relationship quality, trust and retention. In addition, Al-Refaie et al.'s (2014) study findings reveal a significant impact of relationship quality on the customer lifetime value to the organisation. While exploring the effect of e-CRM on e-loyalty, Alim and Ozuem (2014) showed that e$\mathrm{CRM}$ is effective at strengthening relationship with customers and promoting the development of an attractive virtual community which further enhances satisfaction. Recent studies (Koçoglu and Kirmaci, 2012) have also identified the eCRM antecedents of loyalty in the financial service industry. Therefore, organisational factors need to be positively augmented in the relationship between e-CRM practices and marketing throughput.

The banking industry is a significant sector in Kenya's economy and has seen unprecedented growth and intense competition during the last two decades (Mang'unyi, 2011; Thuo et al., 2011). Internet penetration globally has increased eCRM's popularity as a communication tool and relationship-platform. Diverse forms of e-CRM tactics are being devised, and banks are using technology to facilitate this process and to exploit the opportunities (Lam et al., 2013). This has enabled banks to increase their service offerings to $24 / 7$ without interruption. However, in spite of the many advantages provided by internet-based platforms, they too present challenges including the need for personalised attention and care. It remains an unanswered question why many customers are not able to fully exploit the available electronic/online-based banking facilities provided by their respective banks.

Much research focusing on the influence of e-CRM on the e-customer and eloyalty constructs show mixed results (Abdulfattah, 2012; Alim and Ozuem, 2014; Azila and Noor, 2011; Harrigan et al., 2012; Jamali et al., 2013; Koçoglu and Kirmaci, 2012; Lam et al., 2013; Lendel and Varmus, 2015; Tauni et al., 2014; Thuo et al., 2011). In general, previous studies have alluded to the success a firm can derive from e-CRM and further tried to elucidate its impact on allegiance and satisfaction. This article builds on this assertion and investigates the association between e-CRM and e-loyalty in a developing economy, by reflecting on the differences in the internet or web-based use behaviour with banking services that are rather limited in some instances.

\section{Electronic customer relationship management (e-CRM)}

The conceptual definition of e-CRM would be technology-centred relationship marketing and it ensuing advantages encompassing traditional CRM employed by a 
firm to maintain customer relations (Adalikwu and Adalikwu, 2013; Harrigan et al., 2012; Kim-Soon and Zulkifli, 2012; Lendel and Varmus, 2015). These technologies' use of the internet has enabled organisations to attract new customers, analyse their preferences and behaviours and customise support services (Chan and Lam, 2009; Mekkamol et al., 2013; Tarhini et al., 2015). Whereas e-CRM is technology used in managing relationships, it is also applied to customer approaches employed in business management processes (Lam et al., 2013). According to Adalikwu and Adalikwu (2013) and Dhingra and Dhingra (2013), the focus of e-CRM systems is to increase customer experience, services, value benefits, retain them and craft tactics to encourage loyalty. In essence, e-CRM is for organisational staff's use at all levels of businesses, to enable them interact with customers electronically (Azila and Noor, 2011; Tauni, et al., 2014). A study by Tarhini et al. (2015) and Abu-Shanab and Anagreh (2015) found that eCRM capabilities effected upon eCRM benefits such as enhanced customer service and loyalty. Thus, an understanding of the important role that e-CRM plays within modern organizations is paramount. Online facilities within the banking sector are hence limited to the e-CRM characteristics in relation to customer loyalty.

\section{Components of e-CRM System}

Fundamentally, based on Internet commerce, the electronic transaction cycle covers three phases of online service purchasing namely; pre-service sale information search, at service sale and after service sale (Ismail and Hussin, 2016). According to Alhaiou et al. (2012) each phase of the e-CRM transaction has features (pre-service, during service and post-service) which help solidify relationships over the internet while increasing overall customer satisfaction. Therefore, the aforementioned features of the e-transaction cycle model were used to examine the relationship between e-CRM, e-customer-e-Loyalty and satisfaction. Abdulfattah (2012) mentioned that the pre-service features such as customised alerts, local search engines, customised sites, chats etc., provide information that a customer is able to search and thereafter make a decision to purchase and/or use a service. Therefore, the organisation's website is constructed in such a manner that it increases site traffic while ensuring customer satisfaction and retention. One key aspect to consider is personalisation of communication while making it efficient (e-service quality) that strengthens customer-firm relationship and support customers' final purchase decisions (Zeithaml et al., 2012). A satisfied customer with the e-service available on the internet may lead to product or service purchase and attract the customer to the provider of the service too (Ismail and Hussin, 2016). The organisation therefore, would be able to get more information about the customer for example, via customised alerts and package such information as per individual customer's needs and desires also known as personal marketing (Muro et al., 2013). During-service e-CRM features rely on customer's education to influence online transaction completion (Alhaiou et al., 2012). For a transaction to be fulfilled, service suppliers and customers agree on the conditions based on their negotiation. 
Accordingly, security and privacy are paramount (Ramavhona and Mokwena, 2016). Finally, post-service e-CRM features of the e-transaction cycle basically revolve around customer service. Usually a help desk is established where all customers' correspondence issues with regard to a service or product are channeled thereby creating a 'personal' interaction with the organisation (Ismail and Hussin, 2016). Therefore, the feedback mechanism tools (online self-help functionality, Frequently Asked Questions (FAQs) tool, complaints ability feature and online communities) help firms to integrate all customer interactions on a central platform providing customers with more control on the services they want (Abdulfattah, 2012; Olupot and Kituyi, 2013). The aforementioned features, in essence, determine the e-service quality and are critical for increasing customers' post-purchase satisfaction via 'oneto-one' communication and support from the company's website, since good eservice quality at the post-service e-CRM is believed to increase online customer's eloyalty (Alim and Ozuem, 2014; Koçoglu and Kirmaci, 2012; Lam et al., 2013).

\section{E-customer e-loyalty}

Consumer loyalty is, in essence, a customer's faithfulness to a particular service or brand (Gorondutse, Hilman and Nasidi, 2014; Xiao, Guo, D'Ambra and Fu, 2016). It is the connection which a customer has with a brand. Customers maintain a series of loyalties to organisations whose service they usually consume. Their level of faithfulness with companies also determines their purchasing behaviour. According to Khan and Fasih (2014), encouragement for repeat purchases and a further referral of a product or a service to others amounts to customer loyalty. Despite customer loyalty having mixed findings by many researchers, some for example, Usman et al., 2012) have shown that customer loyalty is measured through buyer behaviour or consumption of a particular service. Some researchers viewed loyalty as behavior, whereas some viewed it as attitude (Gorondutse et al., 2014). Therefore, genuine loyalty can only be achieved when strong and positive attitudes are associated with high levels of repeated patronage. While aiming to fulfill their strategic objectives, banks can gain significantly from customer loyalty since loyalty is an effective tool for generating repeat sales from the customers (Azila and Noor, 2011).

\section{Linking e-CRM, customer e-loyalty and satisfaction}

The advent of new technologies has led to a shift from CRM to e-CRM, and with increasing global penetration of the internet, e-CRM has become increasingly popular communication tool and relationship-building platform (Lam et al., 2013). Organisations therefore are keen to deploy different types of e-CRM strategies to attract, maintain, and enhance customer relationships beneficial to loyalty and organisation's success (Dawn and Chowdhury, 2011). However, relationship management is an initiative that requires commitment, strategic CRM tenets and a mindset in order for it to succeed (Govender, 2004). Alhaiou et al. (2012) postulates that e-CRM infrastructure provides support to valuable customers to remain loyal 
since information stored in the e-CRM data base for instance, assists an organisation look at the actual cost of attracting and retaining the customers. The firm can access new international customers and seize valuable data essential to the firm's competitiveness and market share (Harrigan et al., 2012). Hence, by using this information, more time and resources are directed towards the bank's most profitable customers. Azila and Noor (2011) assert that the association between eCRM and customer loyalty such as the aforesaid, means that the more customers are satisfied, repurchase and spread positive word of mouth about the service provider, the more they tend to perceive longer relationships, trust and commitment with the service provider. Researchers (Safa and Ismail, 2013; Safa and von Solms, 2016) go on to say that perceptions about e-satisfaction and e-trust lead to e-loyalty in customers. As such, loyalty will carry on playing crucial roles in the organisation's competitiveness.

A study by Alhaiou et al. (2012) on the relationship between e-CRM features and e-loyalty of UK online shoppers at the different stages of transaction cycle showed that the use of e-CRM in building consumer relationships affects online consumer satisfaction and loyalty. Abdulfattah (2012) who investigated the effect of various e-CRM features at the different stages of the transaction cycle on customer satisfaction on banks' websites, established that e-CRM influences customer relationships and enhances online customer satisfaction and service quality. Rabbai (2013) confirmed the effect of e-CRM on customer loyalty, while Alim and Ozuem (2014) concluded that e-CRM is effective at strengthening relationships with customers and promoting the development of an attractive virtual community which further enhances satisfaction. Safa and von Solms (2016) contend that for orgnanisations to remain e-commerce positively correlates to customer trust, satisfaction and loyalty. It is against this perspective that this article explores how banks may use e-CRM practices to transform their marketing activities and consequently keep customers loyal, by providing deep insights into e-CRM - eloyalty relationship.

\section{Conceptual framework}

According to Alhaiou et al. (2012), the electronic transaction cycle framework (eTCF) has its origins in electronic customer relationship management, customer loyalty and consumer behaviour research (See section 2.2 for detailed description). e-TCF posits three stages of a transaction namely; pre-transaction, during transaction and post-transaction. The aforementioned characteristics are encountered by the customer during a service purchase, at the time of purchase, and after the purchase (Alhaiou et al., 2012). According to Ismail and Hussin (2016), TCF's value is that it reinforces the three-stage relationships while increasing overall customer satisfaction. By looking at the three parts of a service transaction cycle it is established from existing literature that pre-transaction, duringtransaction and post-transaction features and which form the independent variable (e-CRM) impact on the bank's customer e-loyalty. The dependent variable is e- 
customer e-loyalty concerned with purchase and user behaviour, attitude/strong preferences with the bank and purchasing or service consumption situation. All the features at every stage of the transaction are vital. Recent studies (Abdulfattah, 2012; Ismail and Hussin, 2016) postulated e-CRM features influence on customer satisfaction, service quality, and loyalty (Bilgihan and Bujisic, 2014). In addition, Alim and Ozuem (2014) reiterated that e-CRM characteristics are effective at reinforcing relationship with customers on one hand and promoting the development of an attractive virtual community which significantly impacts on satisfaction and loyalty. Tauni et al. (2014) postulated significant relationship between CRM and customer retention. Marketing research conducted before within the financial services sector has proved that e-CRM features are antecedents of customer loyalty (Abu-Shanab and Anagreh, 2015). Therefore, this article examines the effect of the e-CRM features on customer e-loyalty. The study findings may shed light on the interrelationships among the variables, and help the banking industry to improve the quality of e-CRM activities, thus enhancing customer loyalty. Figure 1 illustrates the conceptual model of the study.

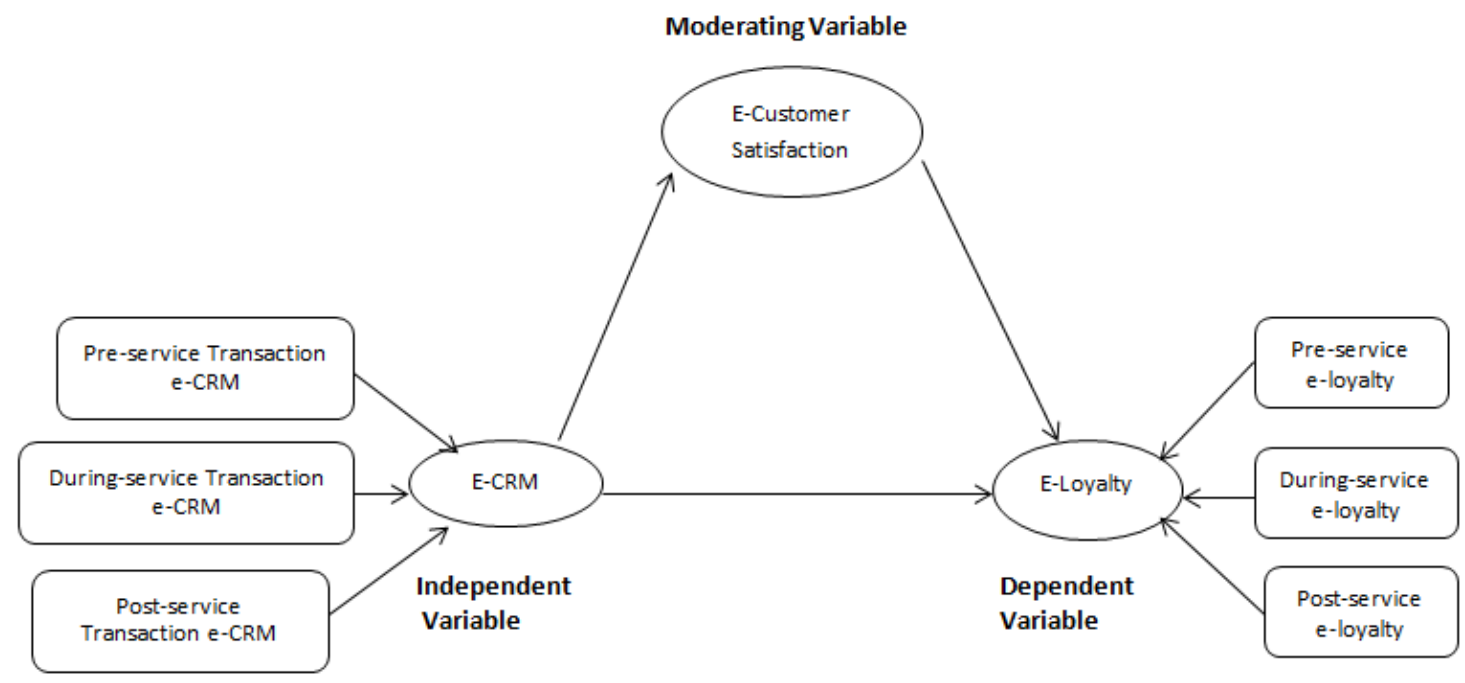

Figure 1. Conceptual model depicting e-CRM customer e-loyalty effect

Source: Authors' own conceptualisation.

Flowing from the literature review, the conceptual framework was developed, and in order to validate the relationships between e-CRM and e-loyalty and related constructs in a developing economy, namely, Kenya, the following hypotheses are formulated:

H1. Features of the pre-service transaction impact customer e-loyalty significantly.

H2. During (the) transaction features impact customer e-loyalty significantly.

H3. Post-transaction features impact customer e-loyalty significantly. 
H4. The e-CRM e-loyalty features (pre-service loyalty, during transaction loyalty and post-transaction loyalty) have a significant positive relationship with the overall customer satisfaction.

$\mathrm{H}_{\mathrm{a}}$ Pre-service e-CRM loyalty has a direct and positive influence on customer satisfaction.

$\mathrm{H} 4 \mathrm{~b}$ During (the) service e-CRM loyalty has a direct and positive influence on customer satisfaction.

$\mathrm{H} 4_{\mathrm{c}}$ Post-service e-CRM loyalty has a direct and positive influence on customer satisfaction.

The above are tested in a Kenyan banking environment, using the research methodology described below.

\section{Methodology}

A quantitative approach and a cross-sectional survey design were chosen because it is an appropriate strategy in establishing relationships between variables and in facilitating collection of discrete numerical data from the population providing current information (Creswell, 2014). The research population consisted of all customers of the Standard Chartered Bank residing in the capital city of Kenya. The unit of analysis was all customers registered and using internet technology-based applications provided by the bank to access their services. Since a complete list of all customers within the headquarters of the bank was not freely available to the researchers, numerous visits were made to the select branch to conduct the survey among the customers who were at the bank during that time, and who met the criteria. The aforementioned bank's headquarters was selected for its convenience, due to the difficulty of collecting data from other branches, about their eCRM performance. In addition, e-CRM had recently been re-launched by the bank therefore it was an opportunity to assess its performance from the customers' standpoint. One of the researchers is an employee of the bank, which made it easier to get permission to conduct the study. The sample was selected using convenience sampling method where a 'bank-intercept survey' strategy was employed in order to gain a representative sample of the customers that constituted a percentage of the total population (Gorard, 2013). Convenience sampling designs generally, have been embraced in service marketing and social science research (Etikan et al., 2016). Therefore, customers who visited the bank for services were invited to participate, and those who agreed to the request were provided with a questionnaire to complete. In addition, the statistical methods applied to test the hypotheses needed to be sufficient enough to perform the relevant statistical analyses. This research comprised three predictor variables, and since it is suggested that for multiple regression analysis the desired level is between 15 and 20 observations for each variable (Hair et al., 2010), the researchers aimed at a sample size of not less than 60. The questionnaires were distributed at 'opportunistic' bank locations such as in the ATM lobby and banking hall. A total of 
78 customers were conveniently surveyed and included in the final sample and their responses were fit for analysis (Lin and Jones, 1997).

Preceding primary data collection was a pilot study conducted in August 2016 among ten participant customers (Saunders et al., 2012; Zikmund and Babin, 2010) who were randomly selected from outside the final sample to assure internal consistency out of their responses of the final instrument. (Sekaran and Bougie, 2016). Hair et al. (2010) argue that a minimum of 0.7 is adequate for early stage of research. The following section presents a discussion on the data collection instrument and its reliability results.

\section{Reliability of the questionnaire}

A five-point Likert scale was used, consisting of six items for each e-CRM stages, eloyalty and customer satisfaction; with anchors of $1=$ strongly disagree and $5=$ strongly agree; $1=$ not at all influential and $5=$ extremely influential; and $1-5$ Likert scale from extremely unlikely and extremely likely respectively. Although the questions per e-CRM variable on the questionnaire were adapted and revised from previous related studies (Abdulfattah, 2012; Alhaiou et al., 2012; Ismail and Hussin, 2016), they were formulated based on the e-TCF aspects keeping in mind that they needed to reflect the local banking context. The questionnaire consisted close-ended questions. Finally, a section was included that required the respondents to supply background data namely; their gender, age, level of education, years of dealing with the bank, duration of use of the bank's internet/electronic-based services, and frequency of use of these services every month. Table 1 which reflects the reliability Cronbach alpha co-efficients for the various measurements reveals that the measures were reliable, since the values fell between .607 and .919. According to Nunnally (1978) and Hair et al. (2010), satisfactory level of reliability is dependent upon how the measure is used, and in some cases, a reliability value of 0.6 is acceptable. Gaskin and Happell (2014) also posits that a set of items must consistently load on the same factor for dependability. The reliability analysis permitted us to proceed with the main study.

Table 1. Reliability of each measured dimension

\begin{tabular}{|l|c|c|}
\hline Dimension & Number of Items & Cronbach's $\boldsymbol{\alpha}$ value \\
\hline Pre-service features & 6 & .754 \\
\hline Pre-service loyalty & 4 & .834 \\
\hline During Service features & 6 & .607 \\
\hline During Service loyalty & 4 & .829 \\
\hline Post Service features & 4 & .741 \\
\hline Post Service loyalty & 4 & .840 \\
\hline Customer satisfaction scale & 6 & .919 \\
\hline
\end{tabular}

Note: KMO (total items $=34)=0.736$; Bartlett's Test of Sphericity $\left(x^{2}=2072.052 ; p<0.001\right)$

Source: Authors' own research. 


\section{Findings}

\section{Descriptive data}

The majority (53.3\%) of the respondents were male, while $46.7 \%$ female. This could imply that more men do their banking using electronic platforms or were willing to participate in the survey than women; because this distribution relied heavily on the random sampling procedure without bias to gender. The dominant age group of the customer respondents was 36-40 years, followed closely by the 31-35 years at 22 (29.3\%). This concurs with the general perception that young adults are more tech savvy and time conscious; they do not want to spend a lot of time queuing to transact at the brick-and-mortar branch and hence find it worthwhile to use the bank's electronic banking channels whenever possible. A significant majority (60\%) held bachelor's degree, and $45.3 \%$ customer respondents had dealt with the bank for 6-10 years. In addition, the majority (52.0\%) of the customer respondents has been using the bank's electronic services for a duration ranging between one and three years and also often uses these services in a month showing a rising trend in the use of electronic banking services among the bank's customers.

Table 2 reflects that the respondents' agreement with the majority of the features ranged from neutral to strong, since the mean scores were all above 3.0. However, some respondents showed low agreement with the following statements: "...receiving rewards, discounts and fee waivers for electronic transactions done" and "ability to customise products and services offerings according to individual needs and desires through electronic services".

Table 2. Respondents' agreement with pre-service, during service and post-service transactions stages attributes in electronic services

\begin{tabular}{|l|c|c|c|}
\hline Measures & Mean & SD & Rank \\
\hline Pre-transactions & & & \\
\hline Need for membership credentials before transacting & 4.16 & 1.115 & 1 \\
\hline Provision of timely information about products/services & 4.12 & .915 & 2 \\
\hline Ability to search information on products/services & 3.84 & 1.014 & 3 \\
\hline Customized, user-friendly and attractive website. & 3.84 & 1.053 & 4 \\
\hline Opportunity to give feedback & 3.47 & 1.166 & 5 \\
\hline Personalised communication via bank's electronic services & 3.40 & 1.230 & 6 \\
\hline During transaction & & & \\
\hline Adherence to security and privacy concerns of customers & 4.41 & .902 & 1 \\
\hline Easy information search & 3.97 & .870 & 2 \\
\hline Availability of alternative transactions and/or payment modes & 3.85 & 1.049 & 3 \\
\hline Queries/complaints are handled/resolved on real-time & 3.37 & 1.112 & 4 \\
\hline Ability to customise products/ services offered according to needs & 2.95 & 1.184 & 5 \\
\hline There are rewards, discounts or fees waivers for e-transactions & 2.28 & 1.300 & 6 \\
\hline Post-transaction & & & \\
\hline Prompt notification on the status of my accounts/obligations etc. & 4.27 & .920 & 1 \\
\hline Ability to channel complaints for resolution vial online platforms & 4.23 & .879 & 2 \\
\hline Existence of electronic options to give feedback & 3.69 & 1.115 & 3 \\
\hline Updated, accurate FAQs platforms & 3.63 & 1.037 & 4 \\
\hline Pre-transaction loyalty & & & \\
\hline
\end{tabular}




\begin{tabular}{|l|c|c|c|}
\hline Measures & Mean & SD & Rank \\
\hline Availability of the bank's products and services & 3.93 & .920 & 1 \\
\hline Decision to recommend the bank to others & 3.89 & 1.122 & 2 \\
\hline Brand preference and likelihood to identify with the bank & 3.83 & 1.132 & 3 \\
\hline Desire to sign up/purchase/repurchase bank's products/services & 3.79 & .949 & 4 \\
\hline During transaction loyalty & & & \\
\hline Availability of the bank's products and services & 3.92 & .850 & 1 \\
\hline Brand preference and likelihood to identify with the bank & 3.88 & .958 & 2 \\
\hline Recommend the bank to a family member, friend or colleague & 3.87 & 1.095 & 3 \\
\hline Desire to sign up/purchase bank's products and services. & 3.83 & .891 & 4 \\
\hline Post-transaction loyalty & & & \\
\hline Brand preference & 3.93 & .963 & 1 \\
\hline Decision to recommend the bank to others & 3.91 & 1.105 & 2 \\
\hline Desire to repurchase the bank's products and services & 3.83 & .891 & 3 \\
\hline Availability of the bank's products and services & 3.81 & 1.087 & 4 \\
\hline Customer satisfaction & & & \\
\hline Urge to use more of the electronic banking services in the future & 4.44 & .702 & 1 \\
\hline I would recommend the e-banking services to others & 4.33 & .723 & 2 \\
\hline I will continue using the bank's e-banking systems and services & 4.29 & .802 & 3 \\
\hline Positive word of mouth about the banks e-services & 4.20 & .788 & 4 \\
\hline I will say positive things about the e-banking services to others & 4.19 & .783 & 5 \\
\hline I would choose this bank again & 4.08 & .850 & 6 \\
\hline
\end{tabular}

Note: The mean scores are based on a 5 -point scale $(1=$ strongly disagree to $7=$ strongly agree); SD = standard deviation.

Source: Authors' own research results.

\section{Exploratory factor analysis}

Exploratory Factor Analysis (EFA) was used to define the underlying constructs or factors among the variables (Hair et al., 2010). By using varimax rotation, factors with eigen values closer to 1.0 were included, and a factor loading of 0.4 was used as a benchmark to include items in a factor (Field, 2009). The Kaiser-Meyer-Olkin (KMO) measure which was used to measure sampling adequacy was 0.736 , while the Bartlett's Test of Sphericity, which assesses whether the variables are adequate for an EFA (Janssen and Laatz, 2013), provided a Chi-square value of 2072.052 (df = 561; sig. 0.001), implying that correlations exist among some of the response categories. However, the data was considered appropriate for factor analysis (Field, 2009; Hair et al., 2010). Based on Kaiser-criterion, the results of the EFA analysis presented in Tables 3 and 4 show the rotated component matrix identified eight factor loadings model with a total variance of $75.4 \%$. 
Table 3. Truncated principle component analysis

\begin{tabular}{|c|c|c|c|c|c|c|c|c|c|}
\hline \multirow[b]{2}{*}{ Var. } & \multicolumn{3}{|c|}{ Initial Eigenvalues } & \multicolumn{3}{|c|}{$\begin{array}{c}\text { Extraction Sums of Squared } \\
\text { Loadings }\end{array}$} & \multicolumn{3}{|c|}{$\begin{array}{c}\text { Rotation Sums of Squared } \\
\text { Loadings }\end{array}$} \\
\hline & Total & \begin{tabular}{|c|}
$\%$ of \\
Variance
\end{tabular} & $\begin{array}{c}\text { Cumulati } \\
\text { ve } \%\end{array}$ & Total & \begin{tabular}{|c|}
$\%$ of \\
Variance
\end{tabular} & $\begin{array}{c}\text { Cumulati } \\
\text { ve } \%\end{array}$ & Total & $\begin{array}{c}\text { \% of } \\
\text { Variance }\end{array}$ & $\begin{array}{c}\text { Cumulati } \\
\text { ve } \%\end{array}$ \\
\hline 1 & 11.377 & 33.460 & 33.460 & 11.377 & 33.460 & 33.460 & 5.978 & 17.584 & 17.584 \\
\hline 2 & 4.230 & 12.441 & 45.902 & 4.230 & 12.441 & 45.902 & 4.217 & 12.403 & 29.987 \\
\hline 3 & 2.713 & 7.980 & 53.882 & 2.713 & 7.980 & 53.882 & 3.980 & 11.707 & 41.694 \\
\hline 4 & 2.054 & 6.041 & 59.923 & 2.054 & 6.041 & 59.923 & 3.148 & 9.259 & 50.953 \\
\hline 5 & 1.702 & 5.005 & 64.927 & 1.702 & 5.005 & 64.927 & 2.505 & 7.367 & 58.320 \\
\hline 6 & 1.351 & 3.974 & 68.902 & 1.351 & 3.974 & 68.902 & 2.308 & 6.787 & 65.107 \\
\hline 7 & 1.139 & 3.349 & 72.251 & 1.139 & 3.349 & 72.251 & 1.787 & 5.256 & 70.363 \\
\hline 8 & 1.087 & 3.196 & 75.447 & 1.087 & 3.196 & 75.447 & 1.728 & 5.084 & 75.447 \\
\hline
\end{tabular}

Source: Authors' own research results.

\section{Factor interpretation}

According to Gaskin and Happell (2014), it is important to check whether the items that load on the same factor are similar in nature (face validity) and make sense when considering EFA solutions and interpretations. Each factor (Table 4) was labelled as follows: factor 1 (customer satisfaction), factor 2 (privacy \& security), factor 3 (interactivity), factor 4 (brand preference), factor 5 (problem solving), factor 6 (user friendliness), factor 7 (customised promotions) and factor 8 (communication platforms). These factors relate to overall 'strategic e-CRM features' to improve and/or strengthen long-term customer-bank relationships. The aforementioned factors are not different to those reported in several previous studies (Alim and Ozuem, 2014; Azila and Noor, 2011; Koçoglu and Kirmaci, 2012; Lam et al., 2013; Olupot and Kituyi, 2013; Rabbai, 2013; Zeithaml et al., 2012).

Table 4. Varimax rotated component loadings

\begin{tabular}{|c|c|c|c|c|c|c|c|c|}
\hline Variable codes & $\begin{array}{c}\text { Factor } \\
1\end{array}$ & $\begin{array}{c}\text { Factor } \\
2\end{array}$ & $\begin{array}{c}\text { Factor } \\
3\end{array}$ & $\begin{array}{c}\text { Factor } \\
4\end{array}$ & $\begin{array}{c}\text { Factor } \\
5\end{array}$ & $\begin{array}{c}\text { Factor } \\
6\end{array}$ & $\begin{array}{c}\text { Factor } \\
7\end{array}$ & $\begin{array}{c}\text { Factor } \\
8\end{array}$ \\
\hline CS_b. & .877 & & & & & & & \\
\hline CS_c. & .845 & & & & & & & \\
\hline CS_a. & .818 & & & & & & & \\
\hline CS_e. & .771 & & & & & & & \\
\hline CS_f. & .749 & & & & & & & \\
\hline CS_d. & .743 & & & & & & & \\
\hline Dur_loy_b4. & .724 & & & & & & & \\
\hline Dur_loy_b3. & .543 & & & & & & & \\
\hline Dur_ser_a1. & & .799 & & & & & & \\
\hline Post_loy_b3. & & .751 & & & & & & \\
\hline pre_loy4. & & .681 & & & & & & \\
\hline pre_loy3. & & .642 & & & & & & \\
\hline Post_loy_b4. & & .641 & & & & & & \\
\hline pre_loy2. & & .521 & & & & & & \\
\hline pre_serv_a3. & & & .860 & & & & & \\
\hline Dur_ser_a3. & & & .729 & & & & & \\
\hline
\end{tabular}




\begin{tabular}{|c|c|c|c|c|c|c|c|c|}
\hline Variable codes & $\begin{array}{c}\text { Factor } \\
1\end{array}$ & $\begin{array}{c}\text { Factor } \\
2\end{array}$ & $\begin{array}{c}\text { Factor } \\
3\end{array}$ & $\begin{array}{c}\text { Factor } \\
4\end{array}$ & $\begin{array}{c}\text { Factor } \\
5\end{array}$ & $\begin{array}{c}\text { Factor } \\
6\end{array}$ & $\begin{array}{c}\text { Factor } \\
7\end{array}$ & $\begin{array}{c}\text { Factor } \\
8\end{array}$ \\
\hline Dur_ser_a2. & & & .670 & & & & & \\
\hline pre_serv_a1. & & & .565 & & & & & \\
\hline Post_serv_a1. & & & .544 & & & & & \\
\hline pre_serv_a2. & & & .540 & & & & & \\
\hline pre_serv_a4. & & & .500 & & & & & \\
\hline Dur_loy_b1. & & & & .821 & & & & \\
\hline Dur_loy_b2. & & & & .772 & & & & \\
\hline pre_loyb1. & & & & .619 & & & & \\
\hline Post_loy_b2. & & & & .510 & & & & \\
\hline Dur_ser_a6. & & & & & .711 & & & \\
\hline Post_serv_a4. & & & & & .711 & & & \\
\hline Post_serv_a3. & & & & & .640 & & & \\
\hline pre_serv_a6. & & & & & & .676 & & \\
\hline pre_serv_a5. & & & & & & .638 & & \\
\hline Dur_ser_a5. & & & & & & & .817 & \\
\hline Dur_ser_a4. & & & & & & & .755 & \\
\hline Post_loy_b1. & & & & & & & & .654 \\
\hline Post_serv_a2. & & & & & & & & .639 \\
\hline
\end{tabular}

Source: Authors' own research results.

\section{The structural model results}

Effects of e-CRM variables at each stage of the transaction cycle

An analysis of the weighting and influence of the dimensions at each stage of a transaction cycle was conducted using standardised regression weights to compare relative effect of the predictor variable against dependent variable (Hair et al., 2010). Figure 2 reveals that all regression weights were as expected. 


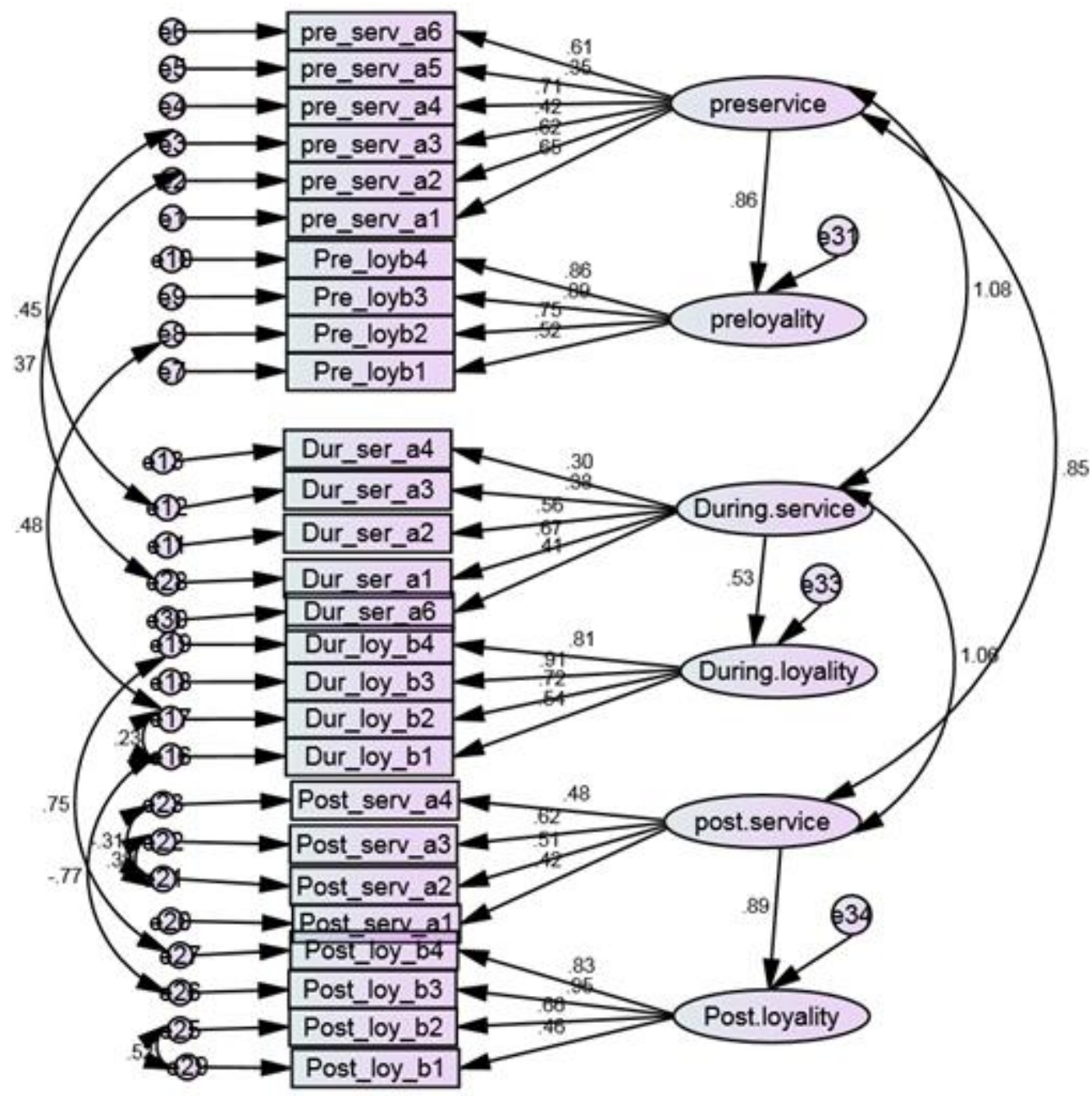

Figure 2. Path diagram representing the measurement model relationship coefficients

Source: Authors' own research results.

Table 5 shows that pre-service $(t=3.861 ; p<0.0001)$ and during service $(t=3.385$; $p<0.0001$ ) highly and significantly influence e-loyalty, while at post-service level, the contribution is merely significant $(t=2.755 ; p=0.006)$. Thus, $\mathrm{H} 1$ to $\mathrm{H} 3$ are supported, and it was concluded that at each stage of a transaction cycle e-CRM characteristics have a strong direct influence on e-loyalty respectively in the Kenyan commercial banking service context. 
Table 5. Regression weights of the structural model

\begin{tabular}{|c|c|c|c|c|c|}
\hline $\begin{array}{lcc}\text { Direct } & \text { relationships } & \text { between } \\
\text { latent } & \text { sub-dimensions } & \text { and e- } \\
\text { loyalty at each transaction stage }\end{array}$ & $\begin{array}{c}\text { Unstd. } \\
\text { Estimate }\end{array}$ & S.E. & C.R. & $\mathbf{P}$ & $\begin{array}{c}\text { Std. } \\
\text { Estimate }\end{array}$ \\
\hline Pre-loyalty<---Pre-service & .846 & .219 & 3.861 & *** & .862 \\
\hline During-loyalty<---During-service & .573 & .169 & 3.385 & $* * *$ & .534 \\
\hline Post-loyalty<---Post-service & .910 & .330 & 2.755 & $.006^{* *}$ & .891 \\
\hline
\end{tabular}

Note: ${ }^{* * *}$ Significant $(p<0.0001) ;{ }^{* *}$ Significant $(p<0.05)$

Source: Authors' own research results.

\section{Relationship between e-CRM loyalty features and customer satisfaction}

Figure 3 and Table 6 illustrate and report the SEM results, which indicate that although there is a positive relationship between pre-loyalty and satisfaction $(t=$ .775; $p>0.0001$ ), it is not significant, and $\mathrm{H} 4 \mathrm{a}$ is supported. Furthermore, during loyalty is positively related to customer satisfaction, and the relationship is highly significant, hence, $\mathrm{H}_{\mathrm{b}} \mathrm{b}$ is also supported $(t=4.377 ; p<0.0001)$. On the other hand, the relationship between post-loyalty and customer satisfaction was negative $(t=-$ $.271 ; p>0.0001$ ) thus, $\mathrm{H}_{\mathrm{c}}$ is not supported, which findings imply that customers are more satisfied with pre-services and during service e-ERM in this commercial banking service context. Overall, the findings do confirm that there is a relationship between customer e-loyalty and satisfaction.

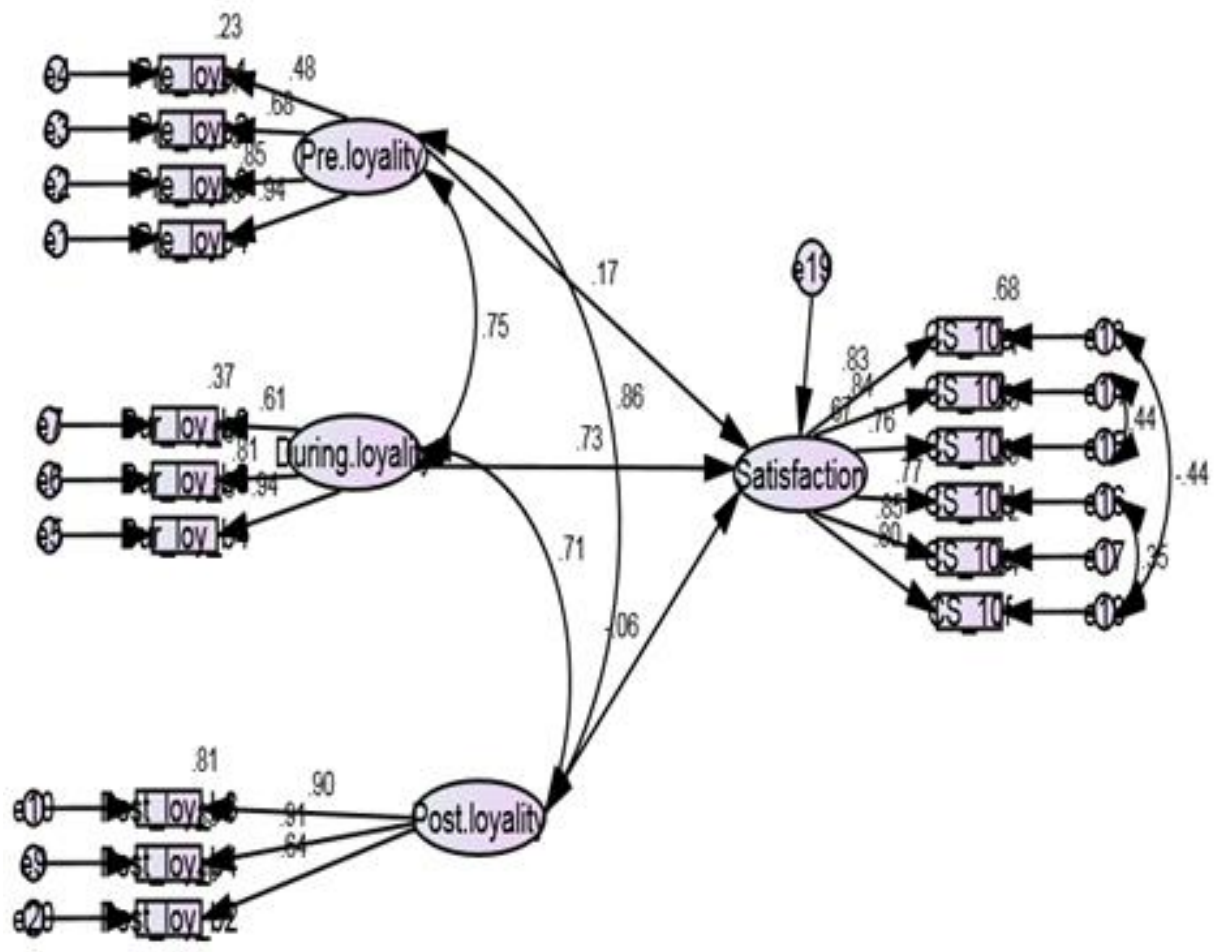

Figure 3. Structural path diagram for standardised estimates

Source: Authors' own research results. 
Table 6. Latent e-CRM loyalty factors and their relationship with satisfaction coefficients

\begin{tabular}{|l|c|c|c|c|c|}
\hline \multicolumn{1}{|c|}{$\begin{array}{c}\text { Relationships between latent } \\
\text { variables and satisfaction }\end{array}$} & $\begin{array}{c}\text { Unstd. } \\
\text { Estimat } \\
\mathbf{e}\end{array}$ & S.E. & $\begin{array}{c}\text { Critica } \\
\text { 1 Ratio }\end{array}$ & P & Estimate \\
\hline Satisfaction<---Pre-loyalty & .094 & .121 & .775 & .438 & .170 \\
\hline Satisfaction<---During-loyalty & .409 & .093 & 4.377 & $* * *$ & .725 \\
\hline Satisfaction<---Post-loyalty & -.032 & .117 & -.271 & .786 &.-055 \\
\hline
\end{tabular}

Note: ${ }^{* *}$ Significant $(\mathrm{p}<0.0001)$

Source: Authors' own research results.

Table 7. Decision on the hypotheses

\begin{tabular}{|c|c|c|}
\hline Hypothesis & Result & Description \\
\hline $\begin{array}{l}\text { H1. Pre-service transaction aspects impact customer } \\
\text { pre e-loyalty significantly. }\end{array}$ & $\begin{array}{c}\mathrm{CR}=3.861 \\
\mathrm{P}=* * *\end{array}$ & Supported \\
\hline $\begin{array}{l}\text { H2. During transaction attributes impact customer } \\
\text { during e-loyalty significantly. }\end{array}$ & $\begin{array}{c}\mathrm{CR}=3.385 \\
\mathrm{P}=* * *\end{array}$ & Supported \\
\hline $\begin{array}{l}\text { H3. Post-transaction features impact customer post e- } \\
\text { loyalty significantly. }\end{array}$ & $\begin{array}{l}\mathrm{CR}=2.755 \\
\mathrm{P}=0.006\end{array}$ & Supported \\
\hline $\begin{array}{l}\text { H4. The e-CRM loyalty features (pre-service loyalty, } \\
\text { during transaction loyalty and post-transaction } \\
\text { loyalty) have a significant positive relationship } \\
\text { with overall customer satisfaction. }\end{array}$ & & *Partially supported \\
\hline 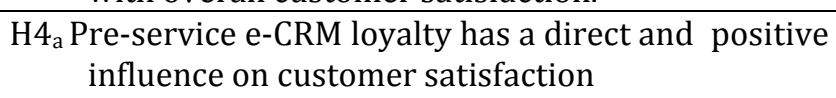 & $\begin{array}{c}\mathrm{CR}=.775 \\
\mathrm{P}=.438\end{array}$ & Supported (ns) \\
\hline $\begin{array}{l}\mathrm{H} 4_{\mathrm{b}} \text { During-service e-CRM loyalty has a direct and } \\
\text { positive influence on customer satisfaction }\end{array}$ & $\begin{aligned} \mathrm{CR} & =4.377 \\
\mathrm{P} & =* * *\end{aligned}$ & Supported \\
\hline $\begin{array}{l}\mathrm{H} 4_{c} \begin{array}{l}\text { Post-service e-CRM loyalty has a direct and } \\
\text { positive influence on customer satisfaction }\end{array}\end{array}$ & $\begin{aligned} \mathrm{CR} & =-.271 \\
\mathrm{P} & =.786\end{aligned}$ & Not supported \\
\hline
\end{tabular}

Note: ${ }^{* * *}$ Highly significant $(\mathrm{p}<0.0001) ;$ ns $=$ Not Significant $(p>0.05)$

Source: Authors' own research results.

\section{Discussion of the findings}

This study empirically investigated the relationships between e-CRM features of a transaction cycle, customer loyalty and satisfaction, in the commercial banking service context. Data from this study were obtained from a survey conducted in Kenya. In general terms, and through factor analysis customers' of the bank most agreed to customer satisfaction, privacy, security, interactivity, brand preference, problem solving, user friendliness, customised promotions and communication platforms. These results are consistent with findings reported in previous 
marketing management studies on e-CRM (Abu-Shanab and Anagreh, 2015; Alhaiou et al., 2012; Alim and Ozuem, 2014; Al-Refaie et al., 2014; Hosseini et al., 2016; Ismail and Hussin, 2016; Koçoglu and Kirmaci, 2012; Lam et al., 2013; Lendel and Varmus, 2015; Muro et al., 2013; Olupot and Kituyi, 2013; Rabbai, 2013; Tarhini et al., 2015; Tauni et al., 2014) suggesting that when developing high-quality e-CRM system, the bank needs to be concerned about how customers will perceive its attributes that would drive satisfaction and consequently loyalty to higher levels.

A positive significant influence was found of e-CRM (pre-service, during service, post-service) transaction features on customers' e-loyalty. This finding indicates that if a bank pays particular attention to the aforesaid characteristics of transaction cycle (i.e. e-CRM system), customers will be more willing to use it. The characteristics within all the aforementioned stages of transaction cycle are all important areas which the bank must consider if it hopes to increase customer loyalty. These findings are consistent with those reported in previous studies (AbuShanab and Anagreh, 2015; Hosseini et al., 2016; Ismail and Hussin, 2016; Lendel and Varmus, 2015; Muro et al., 2013; Zeithaml et al., 2012). In addition, this study provides useful direction of e-CRM characteristics for an organisation to evaluate if its goal is to enhance its management of relationships via an electronic system/s.

Finally, the results indicate satisfaction has a positive relationship with preloyalty and during loyalty respectively, but the relationship is negative with postservices. This finding suggests that efforts to improve customers' satisfaction especially at post-service transaction could significantly improve customer loyalty to bank services. In essence, the aforementioned study results could mean that customer loyalty does not depend on e-CRM characteristics alone, but also depend on customer satisfaction (Abdulfattah, 2012; Alhaiou et al., 2012; Rabbai, 2013).

\section{Conclusions, recommendations and future research}

The findings indicate that e-CRM transaction features are directly and positively associated with customer e-loyalty. Furthermore, despite the fact that the relationship between post-service e-CRM loyalty and customer satisfaction is negative, pre-service e-CRM loyalty and during-service e-CRM loyalty are positively associated with customer satisfaction. Customers' perceptions of satisfaction are an important factor influencing loyalty, and this must be taken into consideration in the electronic banking services relationships. The degree of loyalty among the bank customers seem to differ at each stage of transaction cycle which may be as a result of their satisfaction with the e-CRM system. For example, customer satisfaction is most influenced at pre-service and during service. At the pre-service stage customers gave the highest mean scores to "request for membership credentials before transacting" while during service stage customers scored highest "adherence to security and privacy concerns of customers". The bank managers could take into account by enhancing characteristics of the two transaction cycle stages to meet customers' demands and needs to strengthen customer loyalty. The negative relationship between e-CRM loyalty at post transaction stage and satisfaction could 
suggest that bank managers need to re-examine their e-CRM service offerings at post-transaction stage as this negative relationship could imply customers are not satisfied therefore impacting on their loyalty to the banks services. With respect to customer satisfaction measures, customer gave highest mean score to "urge to use more of the electronic banking services in the future" and "recommending the ebanking services to others". Such findings suggest that bank customers' express higher customer loyalty with respect to the use of the bank's e-CRM services in the future, and are more likely to recommend the services to others.

This study has several limitations. Firstly, it examined customers' perceptions of e-CRM in banks. By only using one bank as a case limits the generalisability of the findings hence, future research could use SEM to investigate other service industries and/or expand the sampling of banks. Second, this research is limited to examining e-CRM in banks from the perception of customers. It would be worthwhile for future research to examine the perceived differences of e-CRM from the points of view of both the providers' and their customers'. Third, there is potential for a replica study on a larger context, using a larger sample and mixed research approaches to get an in-depth feel of perceptions about e-CRM. Finally, studies may be conducted that incorporate other variables identified in literature as affecting customer e-loyalty.

\section{References}

Abdulfattah, F.H. (2012), “The effect of electronic customer relationship on customer satisfaction a study on web banking in Saudi Arabia", PhD Thesis, University of Huddersfield, West Yorkshire, England, available at: eprints.hud.ac.uk/18098/ (accessed June 12, 2016).

Abu-Shanab, E. and Anagreh, L. (2015), "Impact of electronic customer relationship management in banking sector", International Journal of Electronic Customer Relationship Management, Vol. 9, No. 4, pp. $254-270$.

Adalikwu, C. and Adalikwu, J. (2013), "Electronic customer relationship management and consumer behavior", Global Business Research, Vol. 25, No. 2, pp. 139-146.

Ahmad, M.S., Rashid, S. and Ul-Mujeeb, E. (2012), "ECRM and customers: A case of Askari Commercial Bank, Pakistan”, Business Strategy Series, Vol. 13, No. 6, pp. 323-330.

Alhaiou, T.A., Irani, Z. and Ali, M. (2012), "A study on e-CM implementation and eloyalty at different stages of transaction cycle", International Journal of Logistics Systems and Management, Vol. 11, No. 2, pp. 270-284.

Alim, S. and Ozuem, W. (2014), "The influences of e-CRM on customer satisfaction and loyalty in the UK mobile industry", Journal of Applied Business and Finance Researches, Vol. 3, No. 2, pp. 47-54.

Al-Refaie, A., Al-Tahat, M.D. and Bata, N. (2014), “CRM/e-CRM effects on banks performance and customer-bank relationship quality", International Journal of Enterprise Information Systems, Vol. 10, No. 2, pp. 62-80. 
Azila, N. and Noor, M. (2011), "Electronic customer relationship management performance: its impact on loyalty from customers' perspectives", International Journal of e-Education, e-Business, e-Management and $e$ Learning, Vol. 1, No. 1, pp. 1-6.

Bhanu, F. and Magiswary, D. (2010), "Electronic customer relationship management systems (E-CRM): A knowledge management perspective", Proceedings of the International Conference on Education and Management Technology - ICEM, 2010, 2-4 November 2010, IEEE.

Bilgihan, A. and Bujisic, M. (2014), "The effect of website features in online relationship marketing: A case of online hotel booking", Electronic Commerce Research and Applications, Vol. 14, No. 4, pp. 1-11.

Chan, S. and Lam, J. (2009), Customer relationship management on internet and mobile channels: an analytical framework and research directions, Idea Group Inc.

Creswell, J.W. (2014), Research design: Qualitative, quantitative and mixed methods approaches, Sage Publications, Inc., Thousand Oaks.

Dawn, S.K. and Chowdhury, R. (2011), "Electronic customer relationship management (E-CRM): Conceptual framework and developing a model", International Journal of Business and Information Technology, Vol. 1, No. 1, pp. 75-84.

Dhingra, M. and Dhingra, V. (2013), "Determinants of electronic customer relationship management (E-CRM) for customer satisfaction in banking sector in India", African Journal of Business Management, Vol. 7, pp. 762-768.

Dolly, P. and Pruthi, A. (2014), "E-CRM framework: Service to customer perspective", International Journal of Advanced Research in Computer Science and Software Engineering, Vol. 4, No. 4, pp. 1363-1366.

Etikan, I, Musa, S.A. and Alkassim, R.S. (2016), "Comparison of convenience sampling and purposive sampling", American Journal of Theoretical and Applied Statistics, Vol. 5, No. 1, pp. 1-4.

Gaskin, C.J. and Happell, B. (2014), "On exploratory factor analysis: A review of recent evidence, an assessment of current practice, and recommendations for future use", International Journal of Nursing Studies, Vol. 51, pp. 511-521.

Gikenye, W. (2011), "The diffusion of mobile phones for business and information management in Kenya", Proceedings of the European Conference on Information Management 2011, pp. 511- 520, available at: http://connection.ebscohost.com/c/articles/78120473/diffusion-mobilephones-business-information-management-kenya (accessed June 12, 2016).

Gorard, S. (2013), Research design: Robust approaches for marketing, University of Wisconsin, London.

Gorondutse, A.H., Hilman, H. and Nasidi, M. (2014), "Relationship between corporate reputation and customer loyalty on Nigerian food and beverages industry: PLS approach", International Journal of Management \& Business Research, Vol. 4, No. 2, pp. 125-136. 
Govender, C. (2004), "Customer relationship management as a model for growth in banks", MBA thesis, University of KwaZulu-Natal, South Africa, available at: http://hdl.handle.net/10413/2280 (accessed August 4, 2016).

Hair, J.F., Black, W.C., Babin, B.J. and Anderson, R.E. (2010), Multivariate data analysis: A global perspective, Pearson Prentice Hall, New York.

Harrigan, P., Ramsey, E. and Ibbotson, P. (2012), "Entrepreneurial marketing in SMEs: The key capabilities of e-CRM", Journal of Research in Marketing and Entrepreneurship, Vol. 14, No. 1, pp. 40-64.

Hosseini, T., Hosseini, M.H. and Meymand, M.M. (2016), "The effect of performance of electronic customer relationship management (e-CRM) system on accepting electronic banking", Journal of Administrative Management, Education and Training, Vol. 12, No. 3, pp. 357-367.

Ismail, N.A.B. and Hussin, H. (2016), "The effect of E-CRM features on customers' satisfaction for airline e-ticket services in Malaysia", Proceedings of the 6th International Conference on Information and Communication Technology for the Muslim World, IEEE 2016, Conference Publishing Services, pp. 336-343.

Jamali, R., Moshabaki, A., Aramoon, H. and Alimohammadi, A. (2013), "Customer relationship management in electronic environment", The Electronic Library, Vol. 31, No. 1, pp. 119-130.

Janssen, J. and Laatz, W. (2013), Statistical data analysis with SPSS: An applicationoriented introduction to the Basic System and the Module Exact Tests, 8th edition, Springer, Berlin.

Khan, M.M. and Fasih, M. (2014), "Impact of service quality on customer satisfaction and customer loyalty: evidence from banking sector", Pakistan Journal of Commerce and Social Sciences, Vol. 8, No. 2, pp. 331- 354.

Khoshtinat, B., Bojei, J. and Ahmadin, S. (2014), "Integration of task technology fit model and unified theory of acceptance and use of technology to explain eCRM adoption in banking industry", Advances in Environmental Biology, Vol. 8, No. 19, pp. 483-491.

Kihara, S.N. (2015), "The effect of mobile banking on the competitive advantage of commercial banks in Kenya", MBA thesis, United States International University-Africa, available at: erepo.usiu.ac.ke/ (accessed April 5, 2016).

Kim-Soon, N. and Zulkifli, M.F. (2012), "The impact of electronic customer relationship management (e-CRM) on the business performance of small company", Journal of Engineering and Technology, Vol. 3, No. 12, pp. 139-153.

Koçoglu, D. and Kirmaci, S. (2012), "Customer relationship management and customer loyalty; a survey in the sector of banking", International Journal of Business and Social Science, Vol. 3, No. 3, pp. 282-291.

Kumar, N. and Malik, K. (2013), "E-CRM golden opportunity for banks", International Journal of Multidisciplinary and Academic Research, Vol. 2, pp. $1-10$. 
Lam, A.Y.C., Cheung, R. and Lau, M. (2013), "The influence of internet-based customer relationship management on customer loyalty", Contemporary Management Research, Vol. 9, No. 4, pp. 419-440.

Lendel, V. and Varmus, M. (2015), "Proposal of innovative approaches of relationship marketing in business", Business: Theory and Practice, Vol. 16, No. 1, pp. 63-74.

Lin, B. and Jones, C.A. (1997), "Some issues in conducting customer satisfaction surveys", Journal of Marketing Practice: Applied Marketing Science, Vol. 3, No. 1, pp. 4-13.

Mang'unyi, E.E. (2011), "Ownership structure and corporate governance and its effects in performance: A case of selected banks in Kenya", International Journal of Business Administration, Vol. 2, No. 3, pp. 2-18.

Maroofi, F., Darabi, A. and Torabi, J. (2012), "Effects of E-CRM on customer-bank relationship quality and result", International Journal of Academic Research in Accounting, Finance and Management Sciences, Vol. 2, pp. 164-182.

Mekkamol, P., Piewdang, S. and Untachai, S. (2013), "Modeling e-CRM for community tourism in upper Northeastern Thailand", Procedia - Social and Behavioral Sciences, Vol. 88, pp. 108-117.

Muro, M., Magutu, P. and Getembe, K. (2013), "The strategic benefits and challenges in the use of customer relationship management system among commercial banks in Kenya", European Scientific Journal, Vol. 9, pp. 327-349.

Nguyen, B. and Mutum, D. (2012), "A review of customer relationship management: successes, advance, pitfalls and futures", Journal of Business Process Management, Vol. 18, No. 3, pp. 2-4.

Olupot, C. and Kituyi, G.M. (2013), "A framework for the adoption of electronic customer relationship management information systems in developing countries", The Electronic Journal in Electronic Systems in Developing Countries, Vol. 58, No. 3, pp. 1-19.

Rabbai, R.A. (2013), "Investigating the impact of e-CRM on customer loyalty: a case of B2B in Zain company in Jordan", Master in E-Business thesis, Middle East University, Jordan, available at: meu.edu.jo/uploads/1/58749ce6546b1_1.pdf (accessed May 5, 2016).

Ramavhona, T.C. and Mokwena, S. (2016), "Factors influencing Internet banking adoption in South African rural areas", South African Journal of Information Management, Vol. 18, No. 2, a642.

Safa, N.S. and Ismail, M.A. (2013), "A customer loyalty formation model in electronic commerce”, Economic Modelling, Vol. 35, pp. 559-564.

Safa, N.S. and von Solms, R. (2016), "Customers repurchase intention formation in ecommerce", South African Journal of Information Management, Vol. 18, No. 1, pp. 1-9.

Sekaran, U. and Bougie, R.J. (2016), Research methods for business: A skill building approach, 7th edition, John Wiley \& Sons, West Sussex. 
Sivaraks, P., Kirairit, D. and Tang, J.C.S. (2011), "Effects of e-CRM on customer - bank relationship quality and outcomes: The case of Thailand", Journal of High Technology Management Research, Vol. 22, pp. 141-157.

Stojković, D. and Đuričić, R. (2012), "Customer relationship management concept in the electronic business era", Journal of Engineering Management and Competitiveness, Vol. 2, No. 1, pp. 22-26.

Tarhini, A., Mgbemena, C., Trab, M.S.A. and Masa'deh, R. (2015), “User adoption of online banking in Nigeria: A qualitative study", Journal of Internet Banking and Commerce, Vol. 20, No. 3, pp. 1-24.

Tauni, S., Khan, R., Durrani, M. and Aslam, S. (2014), "Impact of customer relationship management on customer retention in the telecom industry of Pakistan", Industrial Engineering Letters, Vol. 4, No. 10, pp. 54 - 59.

Thuo, J.K., Kibera, F.N., K'Obonyo, P.P. and Wainaina, G. (2011), "Customer relationship management and competitiveness of commercial banks in Kenya", Journal of Science Technology Education and Management, Vol. 4, No. 1, pp. 125-141.

Usman, M.Z.U., Jalal, A.N. and Musa, M.A. (2012), "The impact of electronic customer relationship management on consumer's behavior", International Journal of Advances in Engineering and Technology, Vol. 3, No. 1, pp. 500-504.

Xiao, L., Guo, Z., D'Ambra, J. and Fu, B. (2016), "Building loyalty in e-commerce: Towards a multidimensional trust-based framework for the case of China", Program, Vol. 50, No. 4, pp. 431-461.

Zeithaml, V., Bitner, M.J. and Gremler, D. (2012), Services marketing: Integrating customer focus across the firm, 6th edition, McGraw-Hill, India. 